doi: $10.2306 /$ scienceasia1513-1874.2013.39.134

\title{
Efficient plant regeneration in vitro from cotyledon explants of chieh-qua (Benincasa hispida Cogn. var. chieh-qua)
}

\author{
E.E. Liu ${ }^{\mathrm{a}}$, David W.M. Leung ${ }^{\mathrm{b}}$, Qing Hua Xia ${ }^{\mathrm{a}}$, Jie Ren Zheng ${ }^{\mathrm{a}}$, Xin Xiang Peng ${ }^{\mathrm{a}}$, Xiao Ming He ${ }^{\mathrm{c}}$ \\ a College of Life Science, South China Agricultural University, Guangzhou 510642, China \\ b School of Biological Sciences, University of Canterbury, Private Bag 4800, Christchurch 8140, New Zealand \\ c Vegetable Research Institute, Guangdong Academy of Agricultural Sciences, Guangzhou 510640, China
}

${ }^{*}$ Corresponding author, e-mail: xiaominghe@tom.com

Received 13 Aug 2012

Accepted 7 Jan 2013

\begin{abstract}
An efficient plant regeneration system for Benincasa hispida Cogn. var. chieh-qua was developed using explants isolated from mature seeds germinated on moist filter paper under aseptic conditions for 3 days in the dark and 2 days under light. Shoot regeneration frequency (percentage of explant-forming shoots) was about $90 \%$ when the proximal cotyledon portion with a $1 \mathrm{~mm}$-long hypocotyl segment was first cultured on Murashige and Skoog (MS) medium supplemented with $6.0 \mathrm{mg} / \mathrm{l}$ benzylaminopurine (BA) and $0.2 \mathrm{mg} / \mathrm{l}$ naphthalene acetic acid (NAA) for 4 days and then transferred to MS medium containing $1 \mathrm{mg} / \mathrm{l} \mathrm{BA}$ for 4 weeks. About $80 \%$ of the regenerated shoots could elongate further. The root induction medium was half-strength MS medium with $0.01 \mathrm{mg} / \mathrm{l} \mathrm{NAA}$ and $0.01 \mathrm{mg} / \mathrm{l} \mathrm{BA}$. The average rooting frequency was about $93 \%$.
\end{abstract}

KEYWORDS: adventitious shoot formation, organogenesis, pre-culture, hairy melon

\section{INTRODUCTION}

Chieh-qua (Benincasa hispida Cogn. var. chieh-qua How, hairy melon) is a primary vegetable crop in South China and is a member of the Cucurbitaceae crops. In recent years, as a result of the ever expanding and more intense cropping, there is an increasing threat of more frequent outbreaks of diseases which would severely curtail the hairy melon supply. Therefore, there is a great urgency to develop new disease-resistant chieh-qua germplasm. One effective approach to solve this problem is the use of genetic engineering to transfer heterologous disease-resistance genes into existing germplasm of chieh-qua. An important prerequisite for a successful plant transformation is the development of a yet unavailable efficient plant regeneration system in vitro for chieh-qua ${ }^{1}$.

Up to now, there have been a number of studies on in vitro regeneration of several Cucurbitaceae crops including cucumber ${ }^{2,3}$, watermelon ${ }^{4,5}$, melon ${ }^{6}$, squash $^{7,8}$, bottle gourd ${ }^{9}$, figleaf gourd ${ }^{10}$, ash gourd ${ }^{11}$, muskmelon ${ }^{12}$, and chieh-qua ${ }^{1}$. However, only in cucumber, watermelon, squash, and melon, efficient and reliable plant regeneration protocols have been established. The regeneration system of chieh-qua is still problematic because the frequency of shoot regeneration was low and unstable (the highest was
$68 \%$ ), and moreover, the adventitious shoots formed were stunted and difficult to elongate, in spite of the effects of photoperiod, genotype, medium type, and various plant growth regulators on explants regeneration had been assayed ${ }^{13}$. Therefore, the present study aimed to optimize regeneration of chieh-qua by analysing the effects of plant growth regulators, preculture treatments, and different explant types.

\section{MATERIALS AND METHODS}

\section{Seed germination under aseptic conditions}

Seeds of an inbred line of chieh-qua called A39 provided by Guangdong Province Agricultural Institute, China, were used. Seed coats were removed and then disinfected with $5 \%(\mathrm{v} / \mathrm{v})$ sodium hypochlorite for $15 \mathrm{~min}$ followed by five rinses with sterile distilled water. Then, about 20 disinfected seeds were placed on a paper bridge dipped in sterile deionized water in an Erlenmeyer flask. A growth room kept at $25^{\circ} \mathrm{C}$ with the following illumination conditions was used for seed germination: 3 days in the dark followed by 2 days of a $12 / 12 \mathrm{~h}$ photoperiod with irradiance of $40 \mu \mathrm{mol} \mathrm{m}{ }^{-2} \mathrm{~s}^{-1}$.

\section{Plant regeneration experiments}

Five types of explants were prepared for investigation of their response to the induction of shoot regeneration 
in vitro. Firstly, the root of an aseptically grown chieh-qua seedling was excised and discarded. Then the cotyledons were cut in the middle into the distal and proximal halves with reference to the point at which the hypocotyl was attached to the cotyledons. The distal cotyledon halves were discarded. The hypocotyl was split longitudinally into two halves each still attached to a proximal cotyledon half. A type 1 explant was a proximal cotyledon half attached to a small portion (about $3 \mathrm{~mm}$ ) of the split hypocotyl. A type 2 explant was the junction region consisting of a small portion (about $1 \mathrm{~mm}$ ) of the proximal cotyledon half still attached to a small portion (about $3 \mathrm{~mm}$ ) of the hypocotyl half. A type 3 explant was the proximal cotyledon half attached to $1 \mathrm{~mm}$-long of the split hypocotyl. Type 4 explants consisted of only the proximal cotyledon halves. Type 5 explants were similar to the type 4 explants except that the $2 \mathrm{~mm}$-long cotyledon segment closest to where the hypocotyl half was attached was excised and discarded. The explants were placed with the adaxial side down on basal Murashige and Skoog (MS) medium supplemented with $3 \%(\mathrm{w} / \mathrm{v})$ sucrose, $6 \mathrm{mg} / \mathrm{l}$ benzylaminopurine (BA) and $0.2 \mathrm{mg} / \mathrm{l}$ naphthalene acetic acid (NAA) for 4 days before they were transferred to MS medium supplemented with $1 \mathrm{mg} / \mathrm{l} \mathrm{BA}$ and $0.2 \mathrm{mg} / \mathrm{l}$ NAA. After 4 weeks of culture, the percentages of explants producing shoots were determined.

To investigate the effect of different concentrations of BA on shoot regeneration, type 3 explants were placed with the adaxial side down on basal MS medium supplemented with $3 \%(\mathrm{w} / \mathrm{v})$ sucrose and different concentrations $(1,2,4$, or $6 \mathrm{mg} / \mathrm{l})$ of $\mathrm{BA}$ in combination with $0.2 \mathrm{mg} / \mathrm{l} \mathrm{NAA}$. To investigate the influence of pre-culture treatments, type 3 explants were pre-cultured on MS medium supplemented with $6 \mathrm{mg} / \mathrm{l} \mathrm{BA}$ and $0.2 \mathrm{mg} / \mathrm{l} \mathrm{NAA}$ for 2, 3, 4, and 5 days, respectively, before they were transferred onto media supplemented with 1,2 , or $4 \mathrm{mg} / \mathrm{l} \mathrm{BA}$ and $0.2 \mathrm{mg} / \mathrm{l}$ NAA. In a follow-up experiment, type 3 explants were pre-cultured for 4 days on medium supplemented with $6 \mathrm{mg} / \mathrm{l} \mathrm{BA}$ and $0.2 \mathrm{mg} / \mathrm{l} \mathrm{NAA}$ before transferred to media supplemented with $1 \mathrm{mg} / \mathrm{l} \mathrm{BA}$ and $0,0.1$, or $0.2 \mathrm{mg} / \mathrm{l}$ NAA. After 4 weeks of culture, the percentages of explants producing shoots (herewith referred to as regeneration frequency in percent) in each treatment were determined.

Elongated shoots were excised and rooted on halfstrength MS medium solidified with $3 \mathrm{~g} / \mathrm{l}$ phytagel, supplemented with $0.01 \mathrm{mg} / \mathrm{l} \mathrm{BA}$ alone or in combination with $0.01 \mathrm{mg} / 1 \mathrm{NAA}$ or $0.05 \mathrm{mg} / \mathrm{l}$ indole-3acetic acid (IAA). The number of roots formed per cultured shoot (root/shoot ratio), percentage of shoots
Table 1 Effect of explant type on shoot regeneration frequency (percentage of explants forming shoots).

\begin{tabular}{llr}
\hline Ex. type & Description of explant & Reg. $(\%)^{*}$ \\
\hline 1 & $\begin{array}{l}\text { Proximal cotyledon portion with } \\
\text { hypocotyl segment }\end{array}$ & $87 \pm 2^{\mathrm{a}}$ \\
& Junction of hypocotyl and cotyledon & $82 \pm 2^{\mathrm{b}}$ \\
3 & $\begin{array}{l}\text { Proximal cotyledon portion with } \\
\text { 1 mm-long hypocotyl segment }\end{array}$ & $86 \pm 1^{\mathrm{a}}$ \\
4 & $\begin{array}{l}\text { Proximal cotyledon portion } \\
5\end{array}$ & $38 \pm 2^{\mathrm{c}}$ \\
& $\begin{array}{l}\text { Proximal cotyledon portion with } \\
\text { the most proximal 2 mm removed }\end{array}$ & \\
\hline
\end{tabular}

* Values of regeneration followed by a different letter are statistically different at $5 \%$ level.

forming roots (rooting frequency) and root length were determined after about 2 weeks of culture. The $\mathrm{pH}$ of all the media was adjusted to 5.8 prior to the addition of agar $(1 \% \mathrm{w} / \mathrm{v})$ or phytagel as required. All media were autoclaved at $121^{\circ} \mathrm{C}$ for $15 \mathrm{~min}$ before use. There were three replicates (60 explants) in each treatment. All cultures were kept in a growth room at $25^{\circ} \mathrm{C}$ and under a $12 / 12 \mathrm{~h}$ photoperiod with irradiance of $40 \mu \mathrm{mol} \mathrm{m} \mathrm{m}^{-2} \mathrm{~s}^{-1}$.

\section{Data analysis}

For each treatment, data were statistically analysed using a spreadsheet application, and significant differences between various treatments were analysed at $5 \%$ level by Duncan's new multiple range method of DPS v6.55 (DPS Soft Inc., Tang, Hangzhou, China.) analytical software.

\section{RESULTS}

\section{Effect of type of cotyledon explants on shoot regeneration}

Among the five types of explants tested for inducing shoot regeneration, only type 5 explants did not form any shoots. Shoot regeneration frequency was slightly lower in type 2 explants than in type 1 explants. Nevertheless, a majority (more than $80 \%$ ) of type 1 to type 3 explants formed shoots. In contrast, only $38 \%$ of type 4 explants regenerated shoots (Table 1).

\section{Effect of BA on shoot regeneration}

Type 3 explants (proximal cotyledon half attached to $1 \mathrm{~mm}$-long split hypocotyl segment) were cultured on MS medium containing different concentrations of BA in combination with $0.2 \mathrm{mg} / \mathrm{l} \mathrm{NAA}$ for 4 weeks. The percentage of the explants forming shoots was significantly higher on the medium containing $6 \mathrm{mg} / 1$ BA than $1 \mathrm{mg} / \mathrm{l} \mathrm{BA}$. There was no significant difference in the percentage of explants forming shoots on 


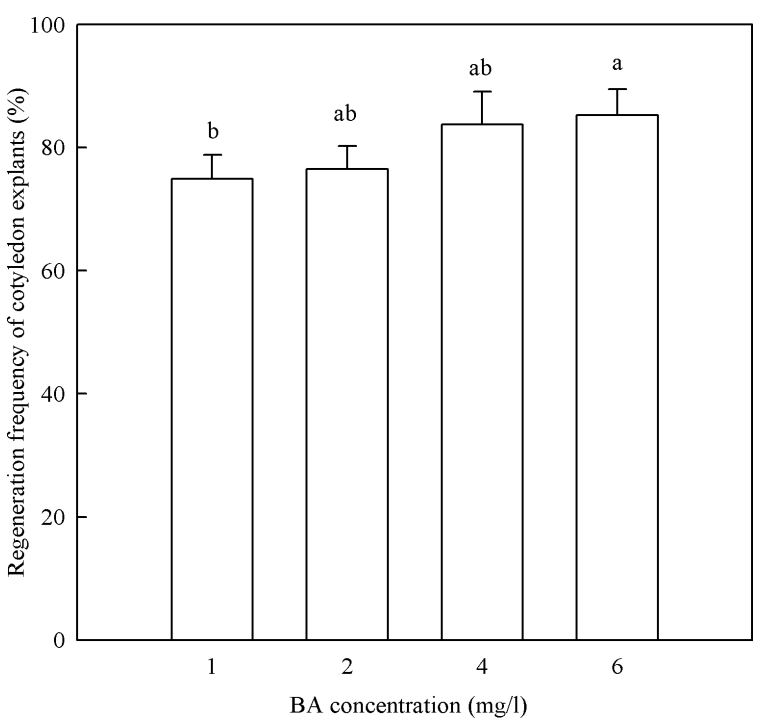

Fig. 1 Effect of different BA concentrations with $0.2 \mathrm{mg} / \mathrm{l}$ NAA on shoot regeneration frequency (percentage of explants forming shoots) in type 3 cotyledon explants of chieh-qua. Data were obtained after 4 weeks of culture.

media containing 2, 4, or 6 mg/l BA (Fig. 1). However, the shoots formed seemed to elongate slightly.

\section{Effect of pre-culture time and transfer to media with varying $B A$ or NAA concentrations}

No obvious effect of the pre-culturing treatments was found as far as the percentage of explants forming shoots after 4 weeks of transfer to medium with $1 \mathrm{mg} / \mathrm{l}$ BA and $0.2 \mathrm{mg} / \mathrm{l} \mathrm{NAA}$ (Fig. 2). However, the shoots in the explants cultured on medium supplemented with $1 \mathrm{mg} / \mathrm{l} \mathrm{BA}$ appeared to elongate more than those in the explants cultured with 2 or $4 \mathrm{mg} / \mathrm{l} \mathrm{BA}$. Following preculture for 4 days, shoot regeneration frequency could reach $90 \%$ when the explants were cultured on MS medium supplemented with $1 \mathrm{mg} / \mathrm{l} \mathrm{BA}$ alone (Fig. 3). The presence of NAA $(0.1$ or $0.2 \mathrm{mg} / \mathrm{l})$ in addition to BA decreased shoot regeneration frequency to about $80 \%$.

\section{Effect of plant growth regulators on in vitro rooting of regenerated shoots}

After 4 weeks of culture, well-developed shoots obtained by pre-culturing explants on the MS media supplemented with $6 \mathrm{mg} / \mathrm{l} \mathrm{BA}$ and $0.2 \mathrm{mg} / \mathrm{l} \mathrm{NAA}$ for 4 days before they were transferred onto MS medium supplemented with $1 \mathrm{mg} / \mathrm{l} \mathrm{BA}$ were excised and rooted. There was no significant difference in rooting frequency (percentage of explants forming roots) whether the shoots were cultured on half-

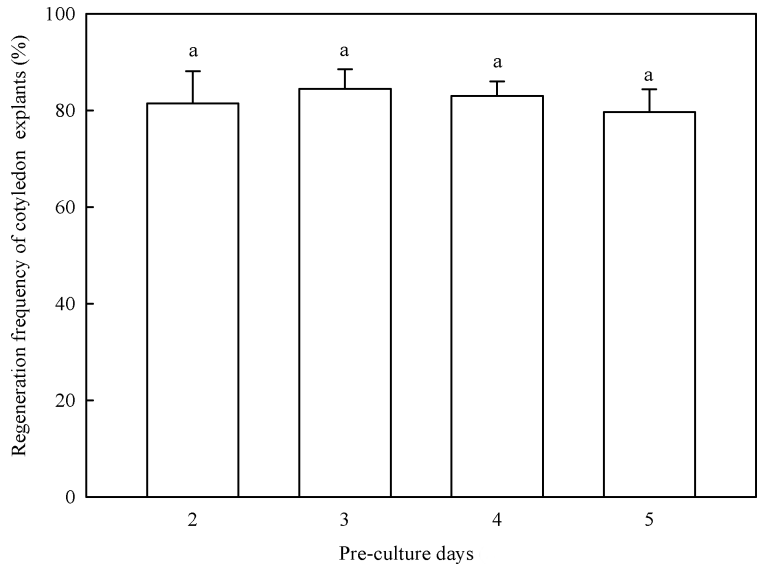

Fig. 2 Effect of pre-culture time on shoot regeneration frequency (percentage of explants forming shoots) in type 3 explants cultured on medium with $6 \mathrm{mg} / \mathrm{l} \mathrm{BA}$ and $0.2 \mathrm{mg} / \mathrm{l}$ NAA. Data were obtained after transfer to followed medium with $1 \mathrm{mg} / \mathrm{l} \mathrm{BA}$ and $0.2 \mathrm{mg} / \mathrm{l} \mathrm{NAA}$ for 4 weeks.

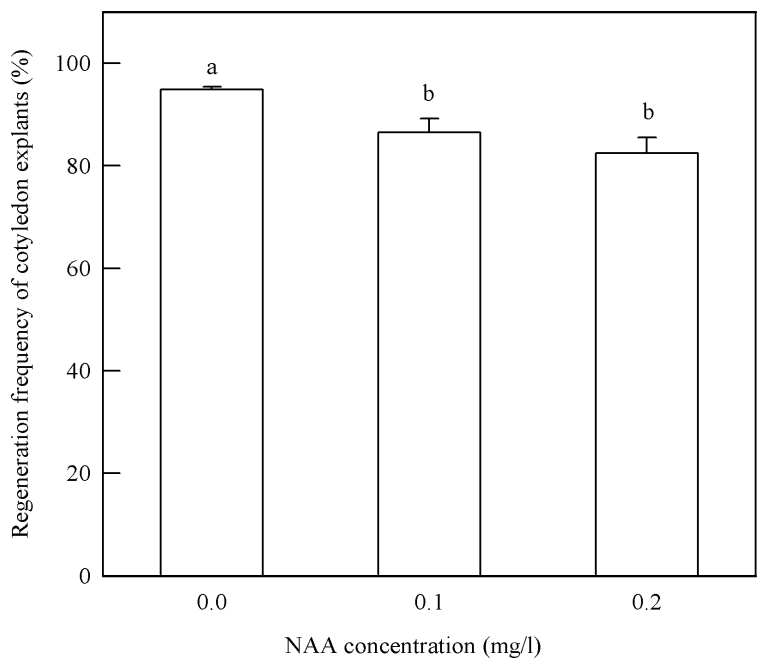

Fig. 3 Shoot regeneration frequency (percentage of explants forming shoots) in type 3 chieh-qua cotyledon explants after transfer to culture media containing $1 \mathrm{mg} / \mathrm{l} \mathrm{BA}$ and different NAA concentrations. The explants were pre-cultured for 4 days on the medium containing $6 \mathrm{mg} / \mathrm{l} \mathrm{BA}$ and $0.2 \mathrm{mg} / \mathrm{l}$ NAA before transferred. Data were obtained after 4 weeks of culture.

strength MS medium supplemented with $0.01 \mathrm{mg} / \mathrm{l}$ BA alone or in combination either with $0.05 \mathrm{mg} / \mathrm{l} \mathrm{IAA}$ or $0.01 \mathrm{mg} / \mathrm{l} \mathrm{NAA}$. But shoots cultured on the medium supplemented with BA alone produced fewer roots per shoot than those cultured on the BA-containing media supplemented with $0.05 \mathrm{mg} / \mathrm{l} \mathrm{IAA}$ or $0.01 \mathrm{mg} / \mathrm{l} \mathrm{NAA}$. Maximum rooting $(100 \%)$ as well as production of 
Table 2 Effect of plant growth regulators on rooting of in vitro regenerated shoots.

\begin{tabular}{|c|c|c|c|}
\hline $\begin{array}{l}\text { Culture medium } \\
(1 / 2 \mathrm{MS}+)\end{array}$ & $\begin{array}{l}\text { Rooting fre- } \\
\text { quency }(\%)^{*}\end{array}$ & $\begin{array}{l}\text { Root/shoot } \\
\text { ratio }\end{array}$ & $\begin{array}{l}\text { Root length } \\
\quad(\mathrm{cm})\end{array}$ \\
\hline $0.01 \mathrm{mg} / \mathrm{BA}$ & $93.9 \pm 5.4^{\mathrm{a}}$ & $4.7 \pm 1.9^{b}$ & $3.6 \pm 1.9^{\mathrm{a}}$ \\
\hline $\begin{array}{l}0.01 \mathrm{mg} / \mathrm{l} \mathrm{BA} \\
+0.01 \mathrm{mg} / \mathrm{l} \mathrm{NAA}\end{array}$ & $93.5 \pm 5.8^{\mathrm{a}}$ & $7.1 \pm 3.1^{\mathrm{a}}$ & $3.3 \pm 1.5^{\mathrm{ab}}$ \\
\hline $\begin{array}{l}0.01 \mathrm{mg} / \mathrm{l} \mathrm{BA} \\
+0.05 \mathrm{mg} / 1 \mathrm{IAA}\end{array}$ & $100.0 \pm 0.0^{\mathrm{a}}$ & $8.0 \pm 3.0^{\mathrm{a}}$ & $3.1 \pm 1.7^{\mathrm{b}}$ \\
\hline
\end{tabular}

* Values of rooting frequency, root/shoot ratio, and root length followed by a different letter, in a row, are statistically different at $5 \%$ level.

normal roots ( 8 roots per shoot) were observed in shoots cultured on the 1/2 MS medium supplemented with $0.01 \mathrm{mg} / \mathrm{l} \mathrm{BA}$ and $0.05 \mathrm{mg} / \mathrm{l}$ IAA. However, there was no significant difference in the number of roots per shoot, root length and rooting frequency of shoots cultured in the media supplemented with IAA and NAA (Table 2).

\section{DISCUSSION}

The type of explant is an important factor for morphogenesis in tissue culture ${ }^{6}$. Preparation and position of the cotyledon explant in relation to other seed parts have a significant effect on the frequency in vitro shoot regeneration in Cucurbitaceae crops. In winter squash, only the cells in the proximal portion of the cotyledon have the potential for adventitious shoot formation ${ }^{8}$. In the present study, the frequency of shoot regeneration was reduced markedly after removing the hypocotyl from the cotyledon and removing the most proximal $2 \mathrm{~mm}$ of the cotyledon resulted in $0 \%$ shoot formation. Likewise, explants with the most proximal $2 \mathrm{~mm}$ of the cotyledons removed led to the loss of shoot regeneration in squash ${ }^{7}$. In pumpkin, cotyledonary explants without the proximal region also failed to regenerate shoots ${ }^{14}$. Similar observations in figleaf gourd $^{10}$, bottle gourd $^{9}$, and soybean ${ }^{15}$ are consistent with the suggestion that the junction of the hypocotyl and proximal half of cotyledon was a highly regenerative region and crucial for adventitious shoot regeneration. These may be related to the differences in endogenous conditions prevalent in different seed parts, especially the level and composition of hormones. Endogenous cytokinins and auxins played an important role in the initiation of meristematic proliferation centre and the subsequent bud primordial dormancy in Pinus pinea ${ }^{16}$. The regeneration frequency of rice callus depended on the endogenous levels of abscisic acid and IAA ${ }^{17}$. The regeneration ability of the pumpkin cotyledon explants was also related to the endogenous isopentenyl adenosine content in cotyledonary explants ${ }^{14}$. In bottle gourd, $\mathrm{AgNO}_{3}$ (an ethylene inhibitor) is able to promote shoot regeneration from proximal cotyledon explants ${ }^{9}$.

Addition of cytokinins to culture media has been reported to be crucial for the induction of adventitious shoot and proliferation in vitro shoot regeneration of numerous Cucurbitaceae such as cucumber, bottle gourd, squashes, and a Cucurbita interspecific hybrid $^{3,7-9,18-20}$. Cytokinin can be used alone or in combination with a low concentration of auxins ${ }^{4,5,14}$. In the present study, the shoot regeneration frequency increased with increasing concentrations of $\mathrm{BA}$, but the adventitious shoots formed in media with high concentrations of BA were stunted in growth and elongated little. The buds regenerated from the cotyledonary nodes of common bean was also significantly enhanced as the concentration of BA increased but beyond the optimum $5 \mathrm{mg} / \mathrm{l}$ the shoot buds appeared to be developmentally suppressed and did not grow further $^{21}$. Interestingly, most of the regenerated shoots could elongate and the regeneration frequency could reach $90 \%$ if the explants were pre-cultured on MS medium containing a combination of $6 \mathrm{mg} / \mathrm{l} \mathrm{BA}$ and $0.2 \mathrm{mg} / \mathrm{l} \mathrm{NAA}$ for 4 days before they were transferred onto MS medium supplemented with $1 \mathrm{mg} / \mathrm{l} \mathrm{BA}$ without any auxin. This is consistent with another study on Celosia showing that it is important to investigate the influence of pre-culture and transfer of explants to media differing in plant growth regulator on elongation of in vitro-derived shoots ${ }^{22}$. In melon, the addition of NAA to subculture medium also reduced shoot regeneration frequencies ${ }^{6}$. The addition of gibberellic acid (GA) to elongation medium had no effects on elongation of adventitious shoots of chieh-qua (data not shown). This is in agreement with the results of Dong and $\mathrm{Jia}^{4}$ on watermelon. In contrast, $99.2 \%$ of adventitious shoots of cucumber could elongate in medium supplemented with $4.44 \mu \mathrm{M}$ BA and $1.44 \mu \mathrm{M}$ $\mathrm{GA}^{18}$. Incorporation of GA and low levels of BA in the shoot elongation media could enhance shoot production of squash ${ }^{7}$. No significant difference was observed in the number of roots per shoot, root length, or rooting frequency of chieh-qua shoots cultured on 1/2 MS medium containing IAA or NAA. However, since NAA is more stable than IAA during culture and IAA has to be filter-sterilized before adding to autoclaved media, NAA is preferred for rooting of in vitro-derived roots of chieh-qua.

The protocol described here is a rapid and reliable in vitro plant regeneration system for chieh-qua via direct shoot organogenesis. The entire process, from 
dry seeds to regenerated plantlets, only requires about two months. In addition, the morphological and physiological variation of shoots regenerated directly from explants could be largely minimized ${ }^{23,24}$. Therefore, this simple and rapid in vitro plant regeneration procedure for chieh-qua is better than indirect adventitious shoot formation via callus formation which was difficult to achieve in chieh-qua. Our protocol can be incorporated into a gene transfer protocol, for example, Agrobacterium tumefaciens-mediated transformation of chieh-qua to develop improved diseaseresistant plants.

Acknowledgements: The present research was supported by the Natural Science Foundation of China (No. 30671423).

\section{REFERENCES}

1. He X, Xie D, Peng Q, Mu L (2007) Plant regeneration from cotyledon of chieh-qua (Benincasa hispida Cogn. var. chieh-qua How). Acta Hort 764, 225-30.

2. Ahmad N, Anis M (2005) In vitro mass propagation of Cucumis sativus L. from nodal segments. Turk $J$ Bot 29, 237-40.

3. Vasudevan A, Selvaraj N, Ganapathi A, Choi CW, Manickavasagam M, Kasthurirengan S (2007) Direct plant regeneration from cucumber embryonal axis. Biol Plantarum 51, 521-4.

4. Dong J-Z, Jia S-R (1991) High efficiency plant regeneration from cotyledons of watermelon (Citrullus vulgaris Schrad). Plant Cell Rep 9, 559-662.

5. Yalcin-Mendia NY, Ipek M, Kacan H, Curuk S, Sari N, Cetiner S, Gaba V (2003) A histological analysis of regeneration in watermelon. $J$ Plant Biochem Biotechnol 12, 147-50.

6. Ntui VO, Thirukkumaran G, Iioka S, Mii M (2009) Efficient plant regeneration via organogenesis in "Egusi" melon (Colocynthis citrullus L). Sci Hort 119, 397-402.

7. Ananthakrishnan G, Xia X, Elman C, Singer S, Paris HS, Gal-On A, Gaba V (2003) Shoot production in squash (Cucurbita pepo) by in vitro organogenesis. Plant Cell Rep 21, 739-46.

8. Lee YK, Chung WI, Ezura H (2003) Efficient plant regeneration via organogenesis in winter squash $(\mathrm{Cu}$ curbita maxima Duch). Plant Sci 164, 413-8.

9. Han J-S, Oh D-G, Mok I-G, Park H-G, Kim CK (2004) Efficient plant regeneration from cotyledon explants of bottle gourd (Lagenaria siceraria Standl). Plant Cell Rep 23, 291-6.

10. Kim K-M, Kim CK, Han J-S (2010) In vitro regeneration from cotyledon explants in figleaf gourd (Cucurbita ficifolia Bouché), a rootstock for Cucurbitaceae. Plant Biotechnol Rep 4, 101-7.

11. Thomas TD, Sreejesh KR (2004) Callus induction and plant regeneration from cotyledonary explants of ash gourd (Benincasa hispida L). Sci Hort 100, 359-67.

12. Yadav RC, Saleh MT, Grumet R (1996) High frequency shoot regeneration from leaf explants of muskmelon. Plant Cell Tissue Organ Cult 45, 207-14.

13. Han W (2009) Optimum of regeneration system and OsOxO1 transformation by Agrobacterium tumefaciens in chieh-qua (Benincasa hispida Cogn. var. chieh-qua How). MSc thesis, South China Agricultural Univ. pp 15-23.

14. Zhang Y, Zhou J, Wu T, Cao J (2008) Shoot regeneration and the relationship between organogenic capacity and endogenous hormonal contents in pumpkin. Plant Cell Tissue Organ Cult 93, 323-31.

15. Mante S, Scorza R, Cordts J (1989) A simple, rapid protocol for adventitious shoot development from mature cotyledons of Glycine max cv. Bragg. Vitro Cell Dev Biol 25, 385-8.

16. Valdés AE, Ordás RJ, Fernández B, Centeno ML (2001) Relationships between hormonal contents and the organogenic response in Pinus pinea cotyledons. Plant Physiol Biochem 39, 377-84.

17. Huang W-L, Lee C-H, Chen Y-R (2012) Levels of endogenous abscisic acid and indole-3-acetic acid influence shoot organogenesis in callus cultures of rice subjected to osmotic stress. Plant Cell Tissue Organ Cult 108, 257-63.

18. Selvaraj N, Vasudevan A, Manickavasagam M, Kasthurirengan S, Ganapathi A (2007) High frequency shoot regeneration from cotyledon explants of cucumber via organogenesis. Sci Hort 112, 2-8.

19. Saha S, Mori H, Hattori K (2007) Synergistic effect of kinetin and benzyladenine plays a vital role in high frequency regeneration from cotyledon explants of bottle gourd (Lagenaria siceraria) in relation to ethylene production. Breed Sci 57, 197-202.

20. Sarowar S, Oh HY, Hyung NI, Min BW, Harn CH, Yang SK, Ok SH, Shin JS (2003) In vitro micropropagation of a Cucurbita interspecific hybrid cultivar-a root stock plant. Plant Cell Tissue Organ Cult 75, 179-82.

21. Dang W, Wei ZM (2009) High frequency plant regeneration from the cotyledonary node of common bean. Biol Plantarum 53, 312-6.

22. Bodhipadma K, Noichinda S, Padyencheun W, Khunthacharoen T, Chikhunthod U, Leung DWM (2011) Influence of preculture treatment and types of explants on shoot growth and in vitro flowering of feathered amaranth (Celosia argentea var. plumose). Plant Cell Tissue Organ Cult 105, 465-9.

23. Burza W, Malepszy S (1995) Direct plant regeneration from leaf explants in cucumber (Cucumis sativus L.) is free of stable genetic variation. Plant Breed 114, 341-5.

24. Plader W, Malepszy S, Burza W, Rusinowski Z (1998) The relationship between the regeneration system and genetic variability in the cucumber (Cucumis sativus L). Euphytica 103, 9-15. 